\title{
Effect of Somatostatin on Repair of Ionizing Radiation-Induced DNA Damage in Pituitary Adenoma Cells GH3
}

\author{
M. ŘEZÁČOVÁ ${ }^{1}$, J. ČÁP ${ }^{2}$, D. VOKURKOVÁ ${ }^{3}$, E. LUKÁŠOVÁ ${ }^{5}$, J. VÁVROVÁ ${ }^{6}$ \\ J. CERMAN ${ }^{1}$, V. MAŠÍN ${ }^{4}$, N. MAZÁNKOVÁ ${ }^{1}$
}

${ }^{1}$ Department of Medical Biochemistry, ${ }^{2}$ Second Department of Internal Medicine, ${ }^{3}$ Institute of Clinical Immunology and Allergology and ${ }^{4}$ Department of Medical Biophysics, Faculty of Medicine and University Hospital in Hradec Králové, Charles University in Prague, Hradec Králové, ${ }^{5}$ Institute of Biophysics, Czech Academy of Sciences, Brno, ${ }^{6}$ Department of Radiobiology, Faculty of Military Health Sciences, University of Defense, Hradec Králové, Czech Republic

Received March 1, 2007

Accepted April 6, 2007

On-line available May 30, 2007

\section{Summary}

Ionizing radiation and somatostatin analogues are used for acromegaly treatment to achieve normalization or reduction of growth hormone hypersecretion and tumor shrinkage. In this study, we investigated a combination of somatostatin (SS14) with ionizing radiation of ${ }^{60} \mathrm{Co}$ and its effect on reparation of radiationinduced damage and cell death of somatomammotroph pituitary cells GH3. Doses of $\gamma$-radiation 20-50 Gy were shown to inhibit proliferation and induce apoptosis in $\mathrm{GH} 3$ cells regardless of somatostatin presence. It has been found that the $D_{0}$ value for GH3 cells was 2.5 Gy. Somatostatin treatment increased radiosensitivity of $\mathrm{GH} 3$ cells, so that $\mathrm{D}_{0}$ value decreased to $2.2 \mathrm{~Gy}$. We detected quick phosphorylation of histone H2A.X upon irradiation by the dose 20 Gy and its colocalization with phosphorylated protein Nbs-1 in the site of double strand break of DNA (DSB). Number of DSB decreased significantly $24 \mathrm{~h}$ after irradiation, however, clearly distinguished foci persisted, indicating non repaired DSB, after irradiation alone or after combined treatment by irradiation and SS14. We found that SS14 alone triggers phosphorylation of Nbs1 ( $p$-Nbs1), which correlates with antiproliferative effect of SS14. Irradiation also increased the presence of $\mathrm{p}$-Nbs1. Most intensive phosphorylation of Nbs1 was detected after combined treatment of irradiation and SS14. The decrease of the number of the DSB foci $24 \mathrm{~h}$ after treatment shows a significant capacity of repair systems of GH3 cells. In spite of this, large number of unrepaired DSB persists for $24 \mathrm{~h}$ after the treatment. We conclude that SS14 does not have a radioprotective effect on somatomammotroph $\mathrm{GH} 3$ cells.

\section{Key words}

Acromegaly • Somatostatin • I onizing radiation - Radiotherapy • Radiosurgery • Apoptosis $\bullet \mathrm{H} 2 \mathrm{~A} . \mathrm{X} \bullet \mathrm{Nbsl} \bullet \mathrm{GH} 3$ cells

\section{Corresponding author}

M. Řezáčová, Dept. of Medical Biochemistry, Faculty of Medicine in Hradec Králové, Šimkova 870, 50038 Hradec Králové, Czech Republic. Fax: +420 495512 715. E-mail rezacovam@lfhk.cuni.cz

\section{Introduction}

Acromegaly treatment has two major goals: to relieve local compression caused by pituitary adenoma and to normalize growth hormone $(\mathrm{GH})$ hypersecretion and insulin-like growth factor 1 (IGF-1) levels. Surgery remains the method of choice for most patients, followed by radiotherapy and pharmacotherapy. Sufficient disease control by surgery alone is achieved in 79-91 \% of microadenomas smaller than $10 \mathrm{~mm}$, but only in $50 \%$ of macroadenomas (Minniti et al. 2003).

Radiotherapy (mainly stereotactic radiosurgery using Leksell gamma knife) is widely used for treatment of residual disease after surgery, or as a first approach in the case of inoperable tumor. Stereotactic radiosurgery causes minimal side effects, preserves physiological functions of pituitary gland and accomplishes more rapid control of GH hypersecretion when compared to traditional fractionated radiotherapy (Landolt et al. 1998). 
Pituitary cells belong among relatively radioresistant cells, doses received by the tumor area during stereotactic radiosurgery session are usually in the range of 20-90 Gy. Effect of ionizing radiation resides mainly in the damage of nuclear DNA, of which the double-strand breaks (DSB) are the most lethal. ATM kinase is considered as primary regulator in response of the cell to DNA damage (Bakkenist and Kastan 2003). Maintenance of genomic integrity is a major challenge for cells which are exposed to genotoxic stress. Eukaryotic cells have thus evolved cell cycle checkpoint mechanisms to detect DNA breaks, replication arrest or defects in mitotic spindle assembly. Acting both during normal cell growth and under perturbed conditions these checkpoint pathways trigger cell cycle arrest in $G_{1} / S, S, G_{2} / M$ or $M$, providing additional time for repair or leading to apoptosis. In our previous work (Mareková et al. 2003) we proved that rat pituitary somatomammotroph adenoma cells GH3 react to irradiation by therapeutically used doses by cell cycle arrest and accumulation in the $\mathrm{G}_{2}$ phase of the cell cycle. Observed apoptosis was slight and started late after irradiation (10 days). This prolonged survival of somatomammotroph cells corresponds with prolonged secretion of growth hormone observed after radiotherapy in acromegalic patients.

ATM kinase acts as upstream regulator in the signaling checkpoint cascade during $\mathrm{G}_{1} / \mathrm{S}$, intra $\mathrm{S}$ and $\mathrm{G}_{2} / \mathrm{M}$ activated in response to DNA DSB. Apoptosis provoked by ionizing radiation is triggered mainly through p53 activation, increase of proapoptotic members of the bcl-2 family followed by release of cytochrome c from mitochondria, apoptosome assembly and finally by activation of caspases. It was recently found that massive activation of ATM is preceded by intensive rearrangements of chromatin surrounding DSB, including rapid phosphorylation of histone H2A.X on serine 139 ( $\gamma$ H2A.X) (Fernandez-Capetillo et al. 2004, Takahashi and Ohnishi 2005). The phosphorylation occurs at a large distance from the site of the damage. Various proteins are then recruited to the sites of DSB (Takahashi and Ohnishi 2005, Fernandez-Capetillo et al. 2004), forming radiation-induced foci (IRIF). These proteins include 53BP1, presumably an adaptor molecule, facilitating formation of protein complexes such as Mre11/Rad50/Nbs1 complex (MRN), repair proteins of both principal processes (homologous recombination and non-homologous end joining), cell-cycle and apoptosis regulators, such as ATM, Chk1 and Chk2 (Bekker-Jensen et al. 2006). Human peripheral lymphocytes represent very radiosensitive cells (Vokurková et al. 2006). In these cells, after irradiation by small doses, DSB are quickly repaired, $\gamma \mathrm{H} 2 \mathrm{~A} . \mathrm{X}$ and $53 \mathrm{BP} 1$ are located in the sites of DSB within minutes after irradiation and during $24 \mathrm{~h}$ DSB are either all repaired or apoptosis is induced. Persistence of IRIF can enhance mutations and causes genome instability. Nothing is known about these processes in pituitary cells.

An important role in acromegaly treatment represents pharmacotherapy with somatostatin analogues (SSA) and recently the GH receptor antagonist. Treatment with SSA is able to normalize GH hypersecretion in 60-70\% and shrink the tumor in about $50 \%$ of cases. SSA are used as a primary conservative therapy or they can be combined both with surgery (tumor shrinkage and the $\mathrm{GH}$ decrease) and with radiotherapy. The main goal in the former case is to control hormone secretion before the radiotherapy effect is sufficient, which usually takes a couple of years. From three possible drug categories (dopamine agonists, SSA or GH antagonists) the somatostatin and its analogs are questioned as to the combined effect with radiotherapy. SSA affects cells via interaction with a specific G-protein coupled membrane receptors. Five distinct subsets of somatostatin receptors (SSTR) have been identified so far, SSTR-1 to SSTR-5 (Patel 1999). Somatostatin reduces the proliferative activity of cells by inhibition of growth factor receptors, leading to cell cycle arrest. Cheung and Boyages (1995) found that somatostatin (SS) and its analog octreotide have cytostatic effect on GH3 cells, and in contrast to ionizing radiation caused cell cycle arrest in the $G_{1}$ phase, but SS has to be renewed in cell culture every $12 \mathrm{~h}$. It has also been shown that somatostatin can target the phosphatidylinositol 3-kinase (PI3K) "survival" pathway (Theodoropoulou et al. 2006).

It has been reported by Landolt et al. (2000) that treatment of patients with SSA octreotide at the time of stereotactic radiosurgery delayed normalization of $\mathrm{GH}$ and IGF-I levels in comparison with patients who did not receive the drug before radiosurgery. The authors suggest that octreotide may act as a radioprotective agent. On the other hand, Castinetti et al. (2005) did not observe significant difference in the success rate of stereotactic radiosurgery whether the patients had been treated by SSA or not.

It should be elucidated whether the antiproliferative effect of SSA overlaps with the cytotoxic effect of gamma-radiation. We decided to study this problem on the somatomammotroph cell line GH3. This 
line is derived from a rat pituitary adenoma that produces $\mathrm{GH}$ and prolactin. In our previous study (Mareková et al. 2003), we demonstrated that irradiation of these cells by the doses of 20 and 50 Gy induces cell death by apoptosis after the $\mathrm{G}_{2} / \mathrm{M}$ arrest, which is long lasting and intensive.

In this study, we demonstrate that irradiation of GH3 cells by the dose of 20 Gy induces $\mathrm{G}_{2} / \mathrm{M}$ arrest, which is not affected by application of SS before the irradiation. We also investigated whether DNA damage induced by irradiation by a dose of $20 \mathrm{~Gy}$ is repaired in GH3 cells and whether this process is affected by application of somatostatin one hour before the irradiation.

\section{Materials and Methods}

\section{Cell culture}

The somatomammotroph cell line, GH3, was obtained from the American Type Culture Collection (ATCC; Manassas, VA, USA). GH3 cells were grown in F10-Ham medium (Sigma-Aldrich) supplemented with $15 \%$ horse serum (Sigma-Aldrich), $2 \%$ fetal bovine serum (Sigma-Aldrich) and glutamine (Sevac, Prague, Czech Republic) in a humidified $37{ }^{\circ} \mathrm{C}$ incubator with a controlled $5 \% \mathrm{CO}_{2}$ atmosphere. Cultures were divided after forming a monolayer by harvesting and diluting to a concentration of $5 \times 10^{5}$ cells $/ \mathrm{ml}$. Cell counts were assessed with a hemocytometer, cell membrane integrity was determined using the Trypan blue exclusion technique. During the experiments the cells (both control and irradiated) were passaged every $72 \mathrm{~h}$. GH3 cells up to ten passages were used for this study.

\section{Gamma irradiation}

Exponentially-growing GH3 cells were suspended to $5 \times 10^{5}$ cells $/ \mathrm{ml}$ in complete medium. $10 \mathrm{ml}$ aliquots were plated into $25 \mathrm{~cm}^{2}$ flasks (Nunc) and after $24 \mathrm{~h}$ irradiated at room temperature using a ${ }^{60} \mathrm{Co} \gamma$-ray source at a dose rate of $3 \mathrm{~Gy} / \mathrm{min}$. After irradiation, flasks were placed in a $37{ }^{\circ} \mathrm{C}$ incubator and removed at various times following irradiation for analysis. The cells were counted and cell viability was determined by a Trypan blue exclusion assay.

\section{Somatostatin (SS14)}

Native cyclic somatostatin-14 was obtained from Sigma-Aldrich. It was diluted in $0.01 \mathrm{~mol} / 1$ acetic acid containing $0.1 \%$ of bovine serum albumin. Aliquots of the solution of $10^{-5} \mathrm{~mol} / \mathrm{l}$ were stored in $-20{ }^{\circ} \mathrm{C}$ and diluted to desired concentration in the culture medium before experiment. Final concentration of SS14 in culture medium during all experiments was $10^{-8} \mathrm{~mol} / \mathrm{l}$.

\section{Cell cycle analysis}

In different time of incubation, cells were washed with cold PBS and fixed with $70 \%$ ethanol. For detection of low molecular-weight fragments of DNA, the cells were incubated for $5 \mathrm{~min}$ at room temperature in buffer $\left(192 \mathrm{ml} 0.2 \mathrm{~mol} / 1 \mathrm{Na}_{2} \mathrm{HPO}_{4}+8 \mathrm{ml} 0.1 \mathrm{~mol} / 1\right.$ citric acid, $\mathrm{pH}$ 7.8) and then stained with propidium iodide (PI) in Vindelov's solution for $60 \mathrm{~min}$ at $37{ }^{\circ} \mathrm{C}$. The DNA content was determined by flow cytometer Cytomics FC500 (Beckman Coulter, Hialeah, FL, USA) using $15 \mathrm{~mW}$ argon-ion laser with excitation capabilities at $488 \mathrm{~nm}$, and the total emission above $560 \mathrm{~nm}$ was recorded. List mode data were analyzed using Multicycle AV software (Phoenix Flow Systems, Inc., San Diego, CA, USA). A minimum of three independent measurements were performed.

\section{Colony assay}

GH3 cells were grown in $25 \mathrm{~cm}^{2}$ culture flasks in complete medium. All cultures were performed in duplicate. Colonies of more than 40 cells were counted after 21 days of incubation in $5 \% \mathrm{CO}_{2}$ at $37{ }^{\circ} \mathrm{C}$. Dose response curves of $\mathrm{GH} 3$ cells irradiated by increasing doses of 0.5-7 Gy were used for $\mathrm{D}_{0}$ value calculations.

\section{Immunocytochemistry}

The cells were fixed with $4 \%$ freshly prepared paraformaldehyde for $10 \mathrm{~min}$ at room temperature (RT), rinsed quickly in PBS, than washed $3 \times 5 \mathrm{~min}$ in PBS, permeabilized in $0.2 \%$ Triton X-100/PBS for $15 \mathrm{~min}$ at $\mathrm{RT}$, rinsed in PBS and washed $2 \times 5 \mathrm{~min}$. Before incubation with primary antibodies (overnight at $4{ }^{\circ} \mathrm{C}$ ), the cells were blocked with $7 \%$ inactivated FCS $+2 \%$ bovine serum albumin in PBS for $30 \mathrm{~min}$ at RT. Antibodies from two different hosts (rabbit and mouse) were used in each slide to detect two different antigens in the same nuclei. For detection of $\gamma \mathrm{H} 2 \mathrm{~A} . \mathrm{X}$ mouse monoclonal anti-phospho-Histone H2A.X (Upstate) and for detection of phosphorylated $\mathrm{Nbs} 1$ rabbit polyclonal Anti-phospho-p95/Nbs1 (Ser343) (CellSignalling) were used. Secondary antibodies: Affinity pure donkey antimouse-FITC-conjugated and affinity pure donkey antirabbit-Cy3-conjugated were purchased from Jackson Laboratory, (Bar Harbor, Maine, USA). The mixture of both antibodies was applied to each slide (after their pre- 
incubation with $5.5 \%$ of donkey serum in PBS for 30 $\min$ at RT) and incubation for $1 \mathrm{~h}$ in dark succeeded by washing ( $3 \mathrm{x} 5 \mathrm{~min}$ ) in PBS. Counterstaining was performed by TOPRO-3 (Molecular Probes, Eugene, OR) in saline sodium citrate prepared fresh from the stock solution.

Images were obtained by high-resolution confocal cytometer based on a completely automated Leica DM RXA fluorescence microscope equipped with CSU-10a confocal unit (Yokogawa, Japan) and a CoolSnap HQ charged-coupled device camera (Photometrix, Melbourne, Australia). Forty optical sections at $0.3 \mu \mathrm{m}$ sections were acquired for each nucleus and stored in the computer memory. The exposition time and dynamic range of camera in the red, green and blue channels were adjusted to the same values for all slides to obtain quantitatively comparable images. Integral optical density (IOD) was measured using image analysis software ImagePro 4.11 (MediaCybernetics, USA).

To check up on a receptor status of GH3 cell line, rabbit antiserum against SSTR of the 2A subtype (human, rat, mouse) was applied for immunocytochemistry (BIOTREND Chemikalien GmbH, Köln, Code No. SS-800) and a peroxidase-labeled streptavidin-biotin system was used for visualization.

\section{Statistical analysis}

The descriptive statistics of the results was calculated and the charts were made in Microsoft ${ }^{\circledR}$ Office Excel 2003 (Microsoft, Inc., Redmond, USA); the detailed statistical analysis was performed in STATISTICA 7 (StatSoft, Inc., Tulsa, USA).

We observed a non-normal distribution of the values of IOD in our results; therefore we chose to present these results as medians and ranges of the values. The Mann-Whitney $U$ test for difference in medians was used to verify differences in the results between the controls and the various experimental groups. Results are shown as median with indicated first and third quartile.

The statistical evaluation of the clonogenic survival curves was performed as follows: At first clonogenic survival curves were approximated by linear combination of orthogonal polynomials. Together the highest polynomial degree was determined with the help of a statistical test by testing of appropriate regression coefficient against zero; the test was rejected on significance level $\alpha=5 \%$. Statistical evaluation of mutual (un)identity of clonogenic survival curves was

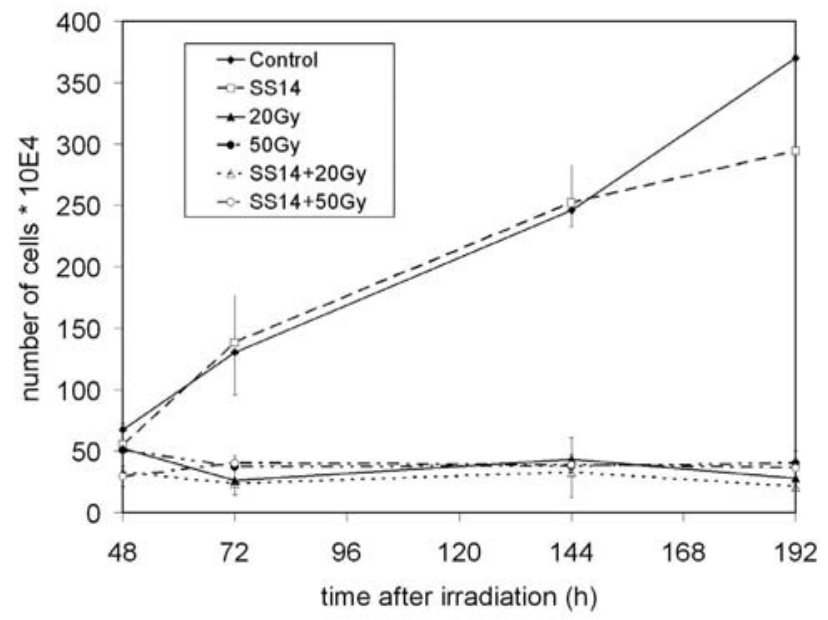

Fig. 1. The effects of irradiation by the doses of 20 and $50 \mathrm{~Gy}$ of $\gamma$ rays of ${ }^{60} \mathrm{Co}$ alone and in combination with SS14 on the number of viable GH3 cells. SS14 was applied to culture medium one hour before the irradiation. Numbers of viable cells were determined by Trypan blue staining. Both doses of radiation inhibit proliferation (number of viable cells does not increase) regardless of SS14 presence. Each point represents mean value \pm S.D. from at least three independent experiments.

provided with the help of two-dependence (two-sided) $\mathrm{t}$-test. It was found from the p-value dependence on the dose or concentration in which dose or concentration range the clonogenic survival curves do not mutually statistically differ and in which domains they are mutually statistically different.

Other results were statistically evaluated with Student's t-test. The values represent the mean \pm S.D. or S.E.M. as indicated in figure legends.

\section{Results}

\section{Cell growth}

At the beginning of the experiment, cells were diluted to the concentration of $5 \times 10^{5} / \mathrm{ml}$. Exponential growth of control cells was apparent during the observation interval (Fig. 1). Somatostatin alone caused only a moderate decrease of the proliferation rate in comparison to the control cells. Both doses of irradiation induced significant inhibition of proliferation (analyzed as the number of viable cells) $(\mathrm{p}<0.01)$ in comparison to the control non-irradiated group. When somatostatin was applied to the culture one hour before gamma irradiation no significant difference in the number of viable cells was observed compared to the cells irradiated in the absence of somatostatin. We also checked on the SSTR-2A receptor status of GH3 cell line. The immunocytochemic detection revealed positively stained structures in the GH3 cells. 


\section{Cell cycle and apoptosis}

After irradiation of GH3 cells with a dose of 20 and 50 Gy in both combinations - without and with SS14 - the cells undergo cell cycle arrest in the $\mathrm{G}_{2} / \mathrm{M}$ phase $48 \mathrm{~h}$ after irradiation and they persist in this phase during 10 days (the time of experiment duration) (Fig. 2A). When gamma radiation was combined with SS14 treatment, arrest in $\mathrm{G}_{2} / \mathrm{M}$ phase was not abrogated. Also apoptosis induction 10 days after irradiation (detected as subG $_{1}$ peak, Fig. 2B) was not significantly different between cells irradiated with and without SS14. However, ten days after irradiation apoptosis was significantly higher in both irradiated groups compared to cells treated with SS14 only (Fig. 2C).

\section{Radiosensitivity}

We examined the effect of SS14 itself on colony forming efficiency after irradiation. Incubation with SS14 alone caused a decreased number of formed colonies. Control cells formed $100.0 \pm 1.0$ colonies/100 cells, cells treated with SS14 formed only $86.5 \pm 10.4$ colonies/100 cells, which correlates with the decreased proliferation rate as mentioned above. We reported previously (Mareková et al. 2003) that the $\mathrm{D}_{0}$ value for $\mathrm{GH} 3$ cells was $2.5 \mathrm{~Gy}$. When cells were simultaneously treated with SS14 and $\gamma$-irradiation, the $\mathrm{D}_{0}$ value decreased to $2.2 \mathrm{~Gy}$ (Fig. 3), indicating a radiosensitizing effect. From the $p(c)$ behavior it was observed that in the dose range up to 3 Gy $p(c) \leq 0.05$ and that therefore both tabular dependencies may be statistically considered as different.

\section{Phosphorylation of H2A.X}

Using confocal microscopy and immunocytochemistry we evaluated phosphorylation of histone H2A.X after irradiation of GH3 cells incubated with and without SS14. SS14 was applied into the culture medium $1 \mathrm{~h}$ before irradiation by the dose of $20 \mathrm{~Gy}$. Exposure of cells to SS14 alone for 2 and $25 \mathrm{~h}$ did not cause DNA damage and a significant increase in $\gamma \mathrm{H} 2 \mathrm{~A} . \mathrm{X}$ was not detected. However, as soon as $1 \mathrm{~h}$ after the irradiation by the dose of $20 \mathrm{~Gy}$, a massive increase in phosphorylation of histone H2A.X was observed and IRIF were formed in the sites of DSB. When irradiation was combined with SS14 treatment, a comparable level of $\gamma \mathrm{H} 2 \mathrm{~A} . \mathrm{X}$ was detected (Figs 4A and 4B). $\gamma \mathrm{H} 2 \mathrm{~A} . \mathrm{X}$ is distributed homogenously in all irradiated cells (Fig. 4C). Increase in integral optical density (IOD) after irradiation of both groups (with or without SS14) was statistically highly significant. $24 \mathrm{~h}$ after the irradiation $63 \%$ (without SS14) and $68 \%$ (with SS14) of cells repaired the DSB and the

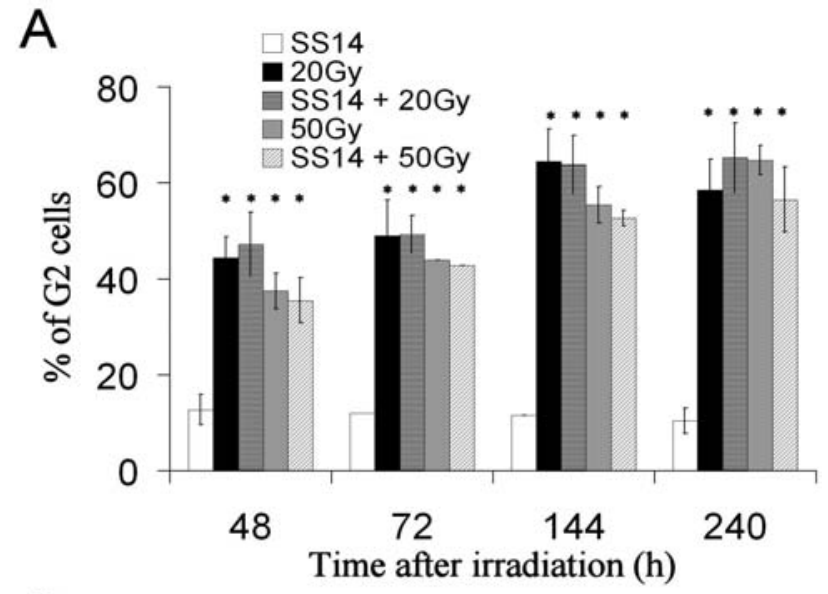

B

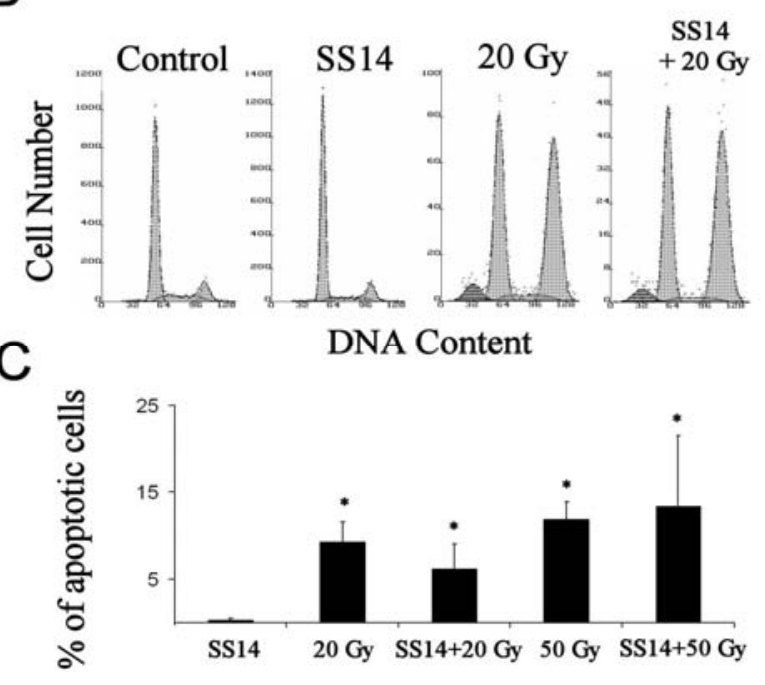

Fig. 2. The effects of $y$ radiation alone and combined with somatostatin treatment on the distribution of $\mathrm{GH} 3$ cells in the cell cycle and apoptosis induction. SS14 was added to culture medium $1 \mathrm{~h}$ before the irradiation. Cell cycle distribution and apoptosis were measured using flow-cytometric detection of DNA content in the cell. A. Dynamics of accumulation of the cells in $G_{2} / M$ phase of the cell cycle. Significant increase in number of cells in $\mathrm{G}_{2} / \mathrm{M}$ phase of the cell cycle can be seen in all irradiated groups in comparison to cells exposed only to SS14 (* $p<0.01$ ). No significant difference in the intensity of $\mathrm{G}_{2} / \mathrm{M}$ cell cycle arrest can be detected between cells irradiated in presence or absence of SS14 ( $p>0.1$ by t-test). Each point represents mean value \pm S.D. from at least three independent experiments. B. Representative results of cell cycle analysis 10 days after the irradiation by the dose of $20 \mathrm{~Gy}$. SS14 alone caused decrease in percentage of cells in $\mathrm{S}$ phase. Intensive accumulation of cells in $\mathrm{G}_{2} / \mathrm{M}$ phase of the cell cycle can be seen in both irradiated groups. In this time irradiated cells in both groups (with and without SS14) undergo apoptosis, which can be detected as subG $_{1}$ peak. C. Induction of apoptosis 10 days after the irradiation. Apoptotic cells were detected as $\mathrm{subG}_{1}$ peak, i.e. cells with less DNA than cells in $\mathrm{G}_{1}$ phase. SS14 alone did not cause apoptosis. In irradiated cells significant apoptosis was induced (* $p<0.01)$, but regardless of SS14 presence $(p=0.48$ for $20 \mathrm{~Gy}$, $p=0.86$ for $50 \mathrm{~Gy})$. Each point represents mean value \pm S.E.M. from at least 3 independent experiments, $p$ calculated by t-test.

amount of $\gamma \mathrm{H} 2 \mathrm{~A} . \mathrm{X}$ in these cells decreased considerably. However, the remaining $37 \%$ and $32 \%$ (with SS14) of the irradiated cells retained a high amount of $\gamma \mathrm{H} 2 \mathrm{~A} . \mathrm{X}$ 


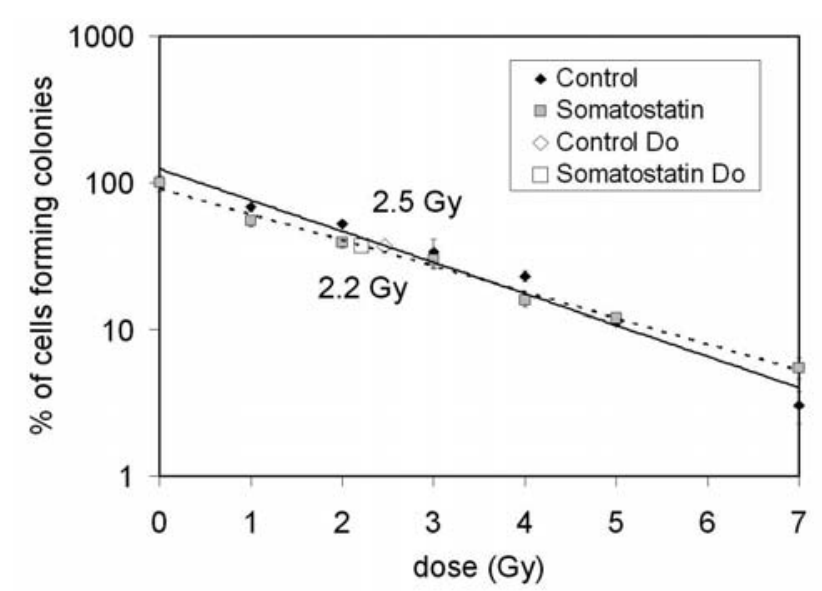

Fig. 3. Dose-response curve for loss of clonogenity of GH3 cells exposed to ionizing $\gamma$ radiation of ${ }^{60} \mathrm{Co}$ in presence or absence of SS14. For the clonogenic survival data, each point is the mean \pm S.D. from 4 measurements from two experiments.

indicating that unrepaired DSB survived (Fig. 4F). Initial cloud-like distribution of $\gamma \mathrm{H} 2 \mathrm{AX}$ in the nuclei of irradiated cells changed during $24 \mathrm{~h}$ after irradiation into clearly distinguished foci (Fig. 4D). This was accompanied by an overall decrease in IOD of green fluorescence per cell (Fig. 4E), but IOD of irradiated cells was still significantly higher than IOD of control cells. The cells receiving combined treatment exhibited more intense phosphorylation of H2A.X, but the difference between the cells irradiated in the absence or presence of SS14 was not significant.

\section{Phosphorylation of Nbs-1}

We also evaluated the phosphorylation of Nbs1 on serine 343 (p-Nbs1). Nbs1 is a part of Mre11/Rad50/Nbs1 complex marking the DSB for repair. Irradiation of GH3 cells leads to a significant increase in phosphorylation of Nbs1, which was detectable both $1 \mathrm{~h}$ and $24 \mathrm{~h}$ after irradiation. SS 14 alone also triggered significant phosphorylation of Nbs-1, but to a much smaller extent. When irradiation was combined with SS14 treatment, the increase in p-Nbs1 $1 \mathrm{~h}$ after the irradiation was significantly higher than in cells irradiated without SS14 (Fig. 4). $24 \mathrm{~h}$ after irradiation the levels of p-Nbs1 in irradiated cells with or without SS14 were comparable (Figs 4B and 4E).

\section{Discussion}

The goal of cancer therapy is the destruction of cancer cells and maximal preservation of the surrounding healthy tissue. To achieve this goal, all therapeutic means try to induce very serious damage of the genomic DNA that would exceed the possibility of the cellular repair mechanisms and force the cell to die. For the time being, it is very difficult to affect specifically only the cancer cells and not to influence the neighboring tissue. Targeted irradiation is a promising approach to this goal.

Ionizing radiation damages the cells through a variety of DNA lesions, of which the DSB are the most difficult to repair. Within minutes of irradiation, chromatin-related machinery responds and the sites of DSB are marked by phosphorylation of histone H2A.X. Various proteins are recruited to this marked chromatin, including proteins regulating cell-cycle arrest and DNA repair, which includes protein $\mathrm{Nbs} 1$ as a part of the repair complex Mre11/Rad50/Nbs1. As we demonstrated previously (Mareková et al. 2003), pituitary GH3 cells respond to therapeutic doses of ionizing radiation by long and intensive accumulation in $\mathrm{G}_{2}$ phase of the cell cycle. It is known from experiments with other cell types that long-term $\mathrm{G}_{2} / \mathrm{M}$ arrest of the cell cycle is related to increased radioresistance, and abrogation/shortening of this cell cycle arrest, such as incubation with ATM kinase inhibitors before and during the irradiation, leads to increased radiosensitivity (Vávrová et al. 2003). The period of cell cycle arrest serves as a repair time, during which the cell attempts to repair the induced DNA damage. The allowed duration of this arrest is dependent on the cell type and its proliferative activity. When the repair is ineffective during the allowed period, the cell activates process of self-destruction by apoptosis. The length of the time of adaptation depends on the duration of the cell cycle. If this time is long and cells are not forced to divide in the tissue, then a cell could persist for long time with non-repaired DNA damage and cell death occurs slowly. Wendt et al. (2006) described at MCF-7 tumor cells radiation-induced permanent $\mathrm{G}_{2} / \mathrm{M}$ arrest of the cell cycle, caused by high expression of protein $\mathrm{p} 21$. The application of caffeine (inhibitor of ATM) before irradiation decreases the expression of p21, abrogates cell cycle arrest and enables apoptosis. For apoptosis induction, cell cycle progression and mitosis should be attempted. Pituitary adenoma cells generally have a very low proliferation rate (Čáp et al. 2003) and long cell cycle. Doubling time of GH3 cell line is approximately $60 \mathrm{~h}$. Ionizing radiation in the dose of 20 Gy completely inhibits proliferation of GH3 cells, which accumulate in the $G_{2}$ phase of the cell cycle and consecutively die by apoptosis. However, apoptosis induction is not very intensive and considerable portion of cells remains 


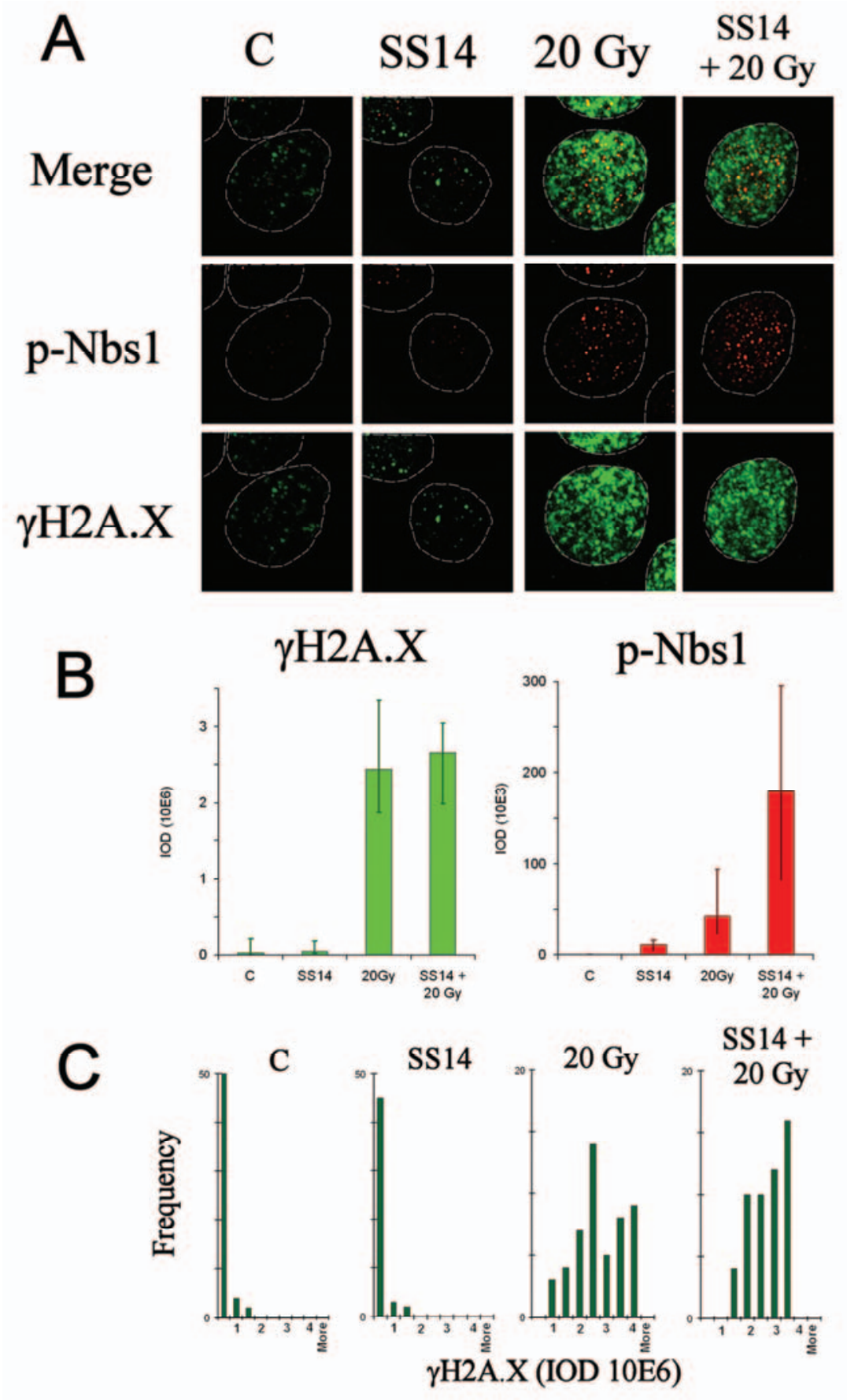

Fig. 4 (A-C). Effect of SS14 on phosphorylation of H2A.X and Nbs1 at GH3 cells $1 \mathrm{~h}(\mathrm{~A}-\mathrm{C})$ after the irradiation by the dose of $20 \mathrm{~Gy}$. SS14 was added to the culture medium $1 \mathrm{~h}$ before the irradiation. Control cells and SS14 pretreated cells were irradiated by 20 Gy of ionizing $\gamma$ radiation of ${ }^{60} \mathrm{Co}$. A: $1 \mathrm{~h}$ after the irradiation the cells were fixed and $\gamma$-H2AX and $\mathrm{p}$-NBS1 were detected by the antibodies. Figure shows representative projections of control cells (C), $2 \mathrm{~h}$ after the addition of SS14 (SS14), $1 \mathrm{~h}$ after the irradiation by the dose of $20 \mathrm{~Gy}(20 \mathrm{~Gy})$ and after the combination of both factors ( $2 \mathrm{~h}$ after the addition of SS14, $1 \mathrm{~h}$ after the irradiation by the dose of 20 Gy). Dashed line outlines cell nuclei. Increase in phosphorylation of H2A.X (green) and Nbs-1 (red) can be seen in both irradiated groups. B: The graphs summarize quantification of the intensity of green ( $\mathrm{YH} 2 \mathrm{~A} . \mathrm{X})$ and red (p-Nbs1) fluorescence measured as integral optical density of each cell. At least 50 cells were analyzed in each sample. The bars represent median $\pm 1^{\text {st }}$ and $3^{\text {rd }}$ quartile. SS14 alone did not significantly increase $\mathrm{YH} 2 \mathrm{~A} . \mathrm{X}(\mathrm{p}=0.18$ by Mann-Whitney test), but increased slightly but significantly $\mathrm{p}$-Nbs1 $(p<0.01)$. Level of $\mathrm{\gamma H} 2 \mathrm{~A} . \mathrm{X}$ increased in both irradiated groups significantly $(p<0.01)$, but with no significant effect of SS14 $(p=0.78)$. Phosphorylation of Nbs1 was stimulated by irradiation alone as well as in combination with SS14. The combination of both factors was significantly more effective than both factors alone $(p<0.01)$. C: The histograms show incidence frequency of cells with increasing amount of $y \mathrm{H} 2 \mathrm{~A} . \mathrm{X} 1 \mathrm{~h}$ after the irradiation. Vast majority $(90 \%)$ of control cells and cells treated with SS14 has IOD for green fluorescence lower than 500 000. Upon irradiation a homogeneous increase in $\mathrm{YH} 2 \mathrm{~A}$.X is observed in all irradiated cells. In both irradiated groups all cells have IOD higher than 500 000, which indicates induction of DNA damage and cellular reaction to DSB. 

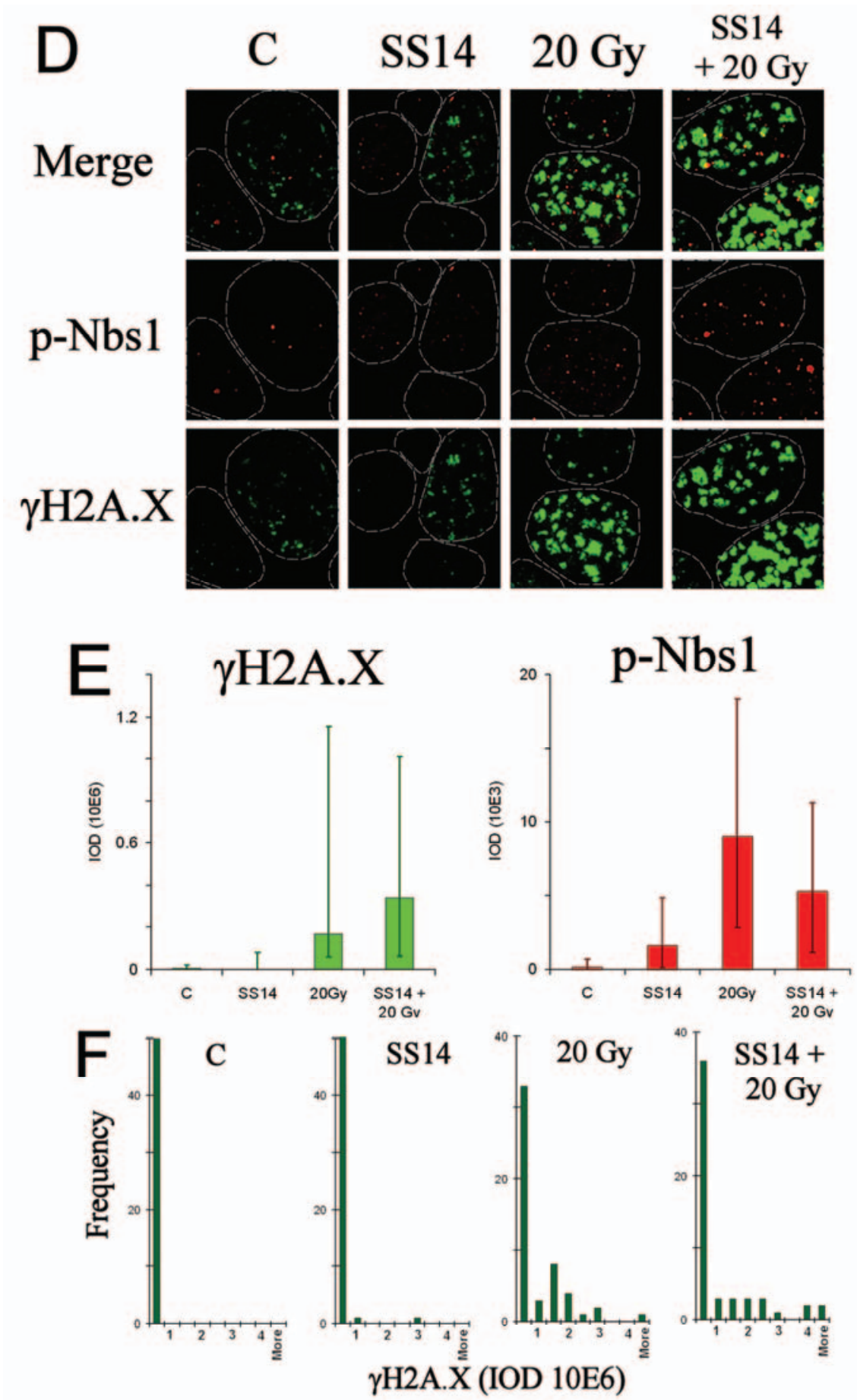

Fig. 4 (D-F). Effect of SS14 on phosphorylation of H2A.X and Nbs1 at GH3 cells $24 \mathrm{~h}$ (D-F) after the irradiation by the dose of 20 Gy. SS14 was added to the culture medium $1 \mathrm{~h}$ before the irradiation. Control cells and SS14 pretreated cells were irradiated by $20 \mathrm{~Gy}$ of ionizing $\gamma$ radiation of ${ }^{60} \mathrm{Co}$. D: $24 \mathrm{~h}$ after the irradiation the cells were fixed and stained with indicated antibodies. Dashed line outlines cell nuclei. Phosphorylated H2A.X (green) and Nbs-1 (red) form distinct foci around non repaired DSB. E: The graphs summarize quantification of the intensity of green $(\mathrm{\gamma H} 2 \mathrm{~A} . \mathrm{X})$ and red ( $\mathrm{p}$-Nbs1) fluorescence measured as in Fig. $4 \mathrm{~B} .24 \mathrm{~h}$ after the irradiation value of IOD decreased in both irradiated groups (with and without SS14) in comparison to $1 \mathrm{~h}$ after the irradiation. Level of $y H 2 A . X$ remains increased in both irradiated groups significantly $(p<0.01)$, but with no significant effect of SS14 $(p=0.60)$. Phosphorylation of Nbs1 was still stimulated significantly by irradiation alone as well as in combination with SS14. $24 \mathrm{~h}$ after the irradiation there was no significant difference between irradiation alone and combined treatment $(p=0.06)$. F: The histograms show incidence frequency of cells with increasing amount of $\mathrm{yH} 2 \mathrm{~A} . \mathrm{X} 24 \mathrm{~h}$ after the irradiation. $100 \%$ of control and $97 \%$ of SS14 treated cells have IOD for green fluorescence of $\mathrm{YH} 2 \mathrm{~A}$.X lower than 500 000. Majority of surviving irradiated cells in both groups, with and without SS14, also exhibits low intensity of $\mathrm{YH} 2 \mathrm{~A} . \mathrm{X}$, but significant percentage of irradiated cells retain high ( $>500000)$ amount of $\mathrm{yH} 2 \mathrm{~A} . \mathrm{X}$ ( $37 \%$ in irradiated group and $32 \%$ in irradiated group pretreated by SS14). 
arrested in the $G_{2}$ phase during 10 days after the irradiation. Radiation-induced apoptosis in GH3 cells therefore seems to follow mitosis attempt.

Direct antiproliferative effect of somatostatin results from inhibition of intracellular pathways activated by growth factors. From five identified somatostatin receptors SSTR-1 and SSTR-2 were detected in GH3 cells (Garcia and Myers 1994). Most interest on the action of somatostatin is focused on SSTR-2, as the clinically used SSA octreotide and lanreotide have a high affinity for this receptor subtype. SSTR-2 has been found to play a critical role in the negative control of normal and tumor cell growth (Benali et al. 2000) and the subsequent arrest of cells in $\mathrm{G}_{0} / \mathrm{G}_{1}$ phase of cell cycle. It was also recently demonstrated that SSTR-2 can enhance TNF- $\alpha$ mediated apoptosis (Guillermet-Guibert et al. 2006). Activation of SSTR-1 has also an inhibitory effect on cell growth, but it was found to potentiate the activity of MAP kinase/ERK. MAP kinase/ERK pathway is also activated through SSTR-2B splicing variant, but not through SSTR-2A (Sellers et al. 2000). Generally, the hitherto acquired data suggest that somatostatin and its analogs activate a complicated network of signals leading to both inhibition and activation of the PIK3/Akt "survival" pathway, with general prevailing of inhibitory signals. We chose native SS14 for these experiments in spite of the fact that its analogues are used clinically in acromegaly treatment. Lanreotide and octreotide bind to SSTR-2 and SSTR-5. SOM-230 also binds to SSTR subtypes 1, 3 and 5. Native SS-14 has a high affinity to all five subtypes of somatostatin receptors.

In our work we detected rapid phosphorylation of histone H2A.X upon irradiation by the dose of $20 \mathrm{~Gy}$ and its colocalization with phosphorylated Nbs-1 in the site of DSB. Clearly distinguished foci were observed $24 \mathrm{~h}$ after the irradiation, indicating unrepaired DSB, after both irradiation alone and combined treatment with SS14 and ionizing radiation. The amount of persisting $\gamma \mathrm{H} 2 \mathrm{~A}$.X was not significantly different in the cells receiving combined treatment in comparison to only irradiated cells. Reaction of cells on long-lasting nonrepaired DSB triggers cell cycle arrest in $\mathrm{G}_{2} / \mathrm{M}$ phase. Accumulation of the $\mathrm{GH} 3$ cells in $\mathrm{G}_{2} / \mathrm{M}$ phase upon irradiation occurs regardless of the presence or absence of SS14. The cells consecutively die by apoptosis. When the ability to form colonies was tested, the $\mathrm{D}_{0}$ value corresponding to the dose of radiation, after which $37 \%$ of cells retain their clonogenic ability decreased in the presence of SS14 from 2.5 Gy (radiation alone) to 2.2 Gy
(SS14 + radiation). This indicates that the cells react to lower doses of radiation by a loss of colony-forming ability, which agrees with the theory that permanent $\mathrm{G}_{2} / \mathrm{M}$ cell cycle arrest is a forerunner of apoptosis. Molecular basis of mild radiosensitizing effect of SS14 on GH3 cells remains to be clarified. However, it seems that the interaction of these two factors (irradiation and SS14) can be mediated through PIK3/Akt "survival" pathway. Ionizing radiation is known to activate this pathway, however, after doses used in radiotherapy the apoptotic machinery clearly prevails. On the other hand, it has been reported (Theodoropoulou et al. 2006) that SS14 can inhibit PIK3/Akt. Therefore, after combination of SS14 and $\gamma$-radiation the activation of PIK3/Akt "survival" pathway could be diminished which would support activation of the apoptotic pathway.

What is the role of Nbs1 in these processes? Repair of radiation-induced damage is provided mainly by two distinct and complementary pathways: homologous recombination (HR) and non-homologous end-joining (NHEJ). HR is important for DSB repair during late $S$ and $G_{2}$ phase of the cell cycle, while NHEJ is a more common DSB repair pathway in mammals and predominates in most stages of the cell cycle, mainly in $\mathrm{G}_{0}$ and $\mathrm{G}_{1}$ phases (Karagiannis and El-Osta 2004). Complex Rad50/Mre11/Nbs1 is involved in processing the broken DNA ends, both in HR and NHEJ. After irradiation, Nbs1 relocalizes to the sites of DNA damage and promotes relocalization and binding of ATM and other repair proteins to these sites. ATM is then activated and triggers cell cycle arrest, repair and apoptosis as mentioned above. One of ATM targets is nibrin itself, ATM catalyses phosphorylation of Nbs1 on serine 343 (Kang et al. 2005). Nibrin also stimulates the enzymatic activities of the Mre11/Rad50 complex required for DNA repair processes and DSB processing (Cerosaletti et al. 2006). The precise role of $\mathrm{p}-\mathrm{Nbs} 1$ is not yet fully understood, however, it is required for proper control of $\mathrm{S}$ phase cell-cycle checkpoint and it forms the complex with Mre11/Rad50 that binds very soon to DSB after their induction. We found that SS14 alone triggers significant phosphorylation of Nbs1 even if the phosphorylated $\mathrm{H} 2 \mathrm{AX}$ indicating the presence of DSB was not detected, which correlates with its antiproliferative effect. Irradiation of GH3 cells by the dose of 20 Gy also caused an increase in p-Nbs1. This effect of ionizing radiation was also reported on other cell types (Gatei et al. 2000, Kang et al. 2005). In our work, increased phosphorylation of Nbs1 in GH3 cells was 
detected $2 \mathrm{~h}$ after the beginning of incubation with SS14 or $1 \mathrm{~h}$ after irradiation. The increased level of $\mathrm{p}-\mathrm{Nbs} 1$ persisted for $24 \mathrm{~h}$, but after this period it was approximately 2.7 fold lower than $2 \mathrm{~h}$ after the beginning of incubation with SS14 or $1 \mathrm{~h}$ after the irradiation, respectively. Lasting phosphorylation of $\mathrm{Nbs} 1$ might indicate unrepaired DNA damage and activation of apoptotic pathways through ATM kinase. However, DNA repair and death mechanisms in higher organisms are very complex and involve many proteins, which function is not yet clearly understood.

Our results demonstrate that even after the high dose of ionizing radiation (20 Gy) the majority of radiation-induced DSB is repaired during $24 \mathrm{~h}$ (as demonstrated by $\gamma \mathrm{H} 2 \mathrm{~A} . \mathrm{X}$ decrease). However, this repair is not complete; rather high number of DSB per cell persists which prevent the cells to proliferate and keep the cells permanently arrested in $\mathrm{G}_{2} / \mathrm{M}$ phase of cell cycle. During the experiment we did not observe any proliferation and only small fraction of cells entered apoptosis. Owing to the long duration of the cell cycle in these cells it is possible that cells with DNA damage are not forced to enter apoptosis and this process would have a longer delay. SS14 treatment before irradiation by gamma rays does not influence significantly phosphorylation of histone H2A.X in the sites of DSB induced by $\gamma$-irradiation. However, it triggers phosphorylation of Nbs1 without induction of DSB. SS14 treatment reduces $\mathrm{D}_{0}$ of pituitary cells $\mathrm{GH} 3$ from $2.5 \mathrm{~Gy}$ to $2.2 \mathrm{~Gy}$. We conclude that $\mathrm{SS} 14$ does not have a radioprotective effect on somatomammotroph GH3 cells, but that pretreatment with SS14 might be beneficial for radiation-induced cell death.

\section{Conflict of Interest}

There is no conflict of interest.

\section{Acknowledgements}

This work was supported by the Ministry of Education of the Czech Republic (project No. MSM 0021620820).

\section{References}

BAKKENIST CJ, KASTAN MB: DNA damage activates ATM through intermolecular autophosphorylation and dimer dissociation. Nature 421: 499-506, 2003.

BEKKER-JENSEN S, LUKAS C, KITAGAWA R, MELANDER F, KASTAN MB, BARTEK J, LUKAS J: Spatial organization of the mammalian genome surveillance machinery in response to DNA strand breaks. J Cell Biol 173: 195-206, 2006.

BENALI N, CORDELIER P, CALISE D, PAGES P, ROCHAIX P, NAGY A, ESTEVE JP, POUR PM, SCHALLY AV, VAYSSE N, SUSINI C, BUSCAIL L: Inhibition of growth and metastatic progression of pancreatic carcinoma in hamster after somatostatin receptor subtype 2 (sst2) gene expression and administration of cytotoxic somatostatin analog AN-238. Proc Natl Acad Sci USA 97: 9180-9185, 2000.

ČÁP J, CERMAN J, NĚMEČEK S, MAREKOVÁ M, HÁNA V, FRYŠÁK Z: The influence of treatment with somatostatin analogues on morphology, proliferative and apoptotic activity in GH-secreting pituitary adenomas. J Clin Neurosci 10: 444-448, 2003.

CASTINETTI F, TAIEB D, KUHN JM, CHANSON P, TAMURA M, JAQUET P, CONTE-DEVOLX B, REGIS J, DUFOUR H, BRUE T: Outcome of gamma knife radiosurgery in 82 patients with acromegaly: correlation with initial hypersecretion. J Clin Endocrinol Metab 90: 4483-4488, 2005.

CEROSALETTI K, WRIGHT J, CONCANNON P: Active role for nibrin in the kinetics of Atm activation. Mol Cell Biol 26: 1691-1699, 2006.

CHEUNG NW, BOYAGES S: Somatostatin-14 and its analog Octreotide exert a cytostatic effect on GH3 rat pituitary tumor cell proliferation via a transient $\mathrm{G}_{0} / \mathrm{G}_{1}$ cell cycle block. Endocrinology 136: 4174-4181, 1995.

FERNANDEZ-CAPETILLO O, LEE A, NUSSENZWEIG M, NUSSENZWEIG A: H2AX: the histone guardian of the genome. DNA Repair (Amst) 3: 959-967, 2004.

GARCIA PD, MYERS RM: Pituitary cell line GH3 expresses two somatostatin receptor subtypes that inhibit adenylyl cyclase: functional expression of rat somatostatin receptor subtypes 1 and 2 in human embryonic kidney 293 cells. Mol Pharmacol 45: 402-409, 1994. 
GATEI M, YOUNG D, CEROSALETTI KM, DESAI-MEHTA A, SPRING K, KOZLOV S, LAVIN MF, GATTI RA, CONCANNON P, KHANNA K: ATM-dependent phosphorylation of nibrin in response to radiation exposure. Nat Genet 25: 115-119, 2000.

GUILLERMET-GUIBERT J, SAINT-LAURENT N, DAVENNE L, ROCHAIX P, CUVILLIER O, CULLER MD, PRADAYROL L, BUSCAIL L, SUSINI C, BOUSQUET C: Novel synergistic mechanism for sst2

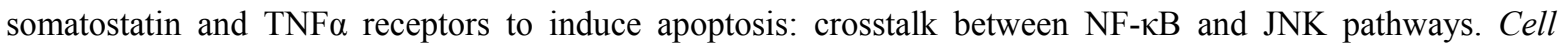
Death Differ 14: 197-208, 2006.

KANG J, FERGUSON D, SONG H, BASSING C, ECKERSDORFF M, ALT FW, XU Y: Functional interaction of H2AX, NBS1, and p53 in ATM-dependent DNA damage responses and tumor suppression. Mol Cell Biol 25 : 661-670, 2005.

KARAGIANNIS TC, EL-OSTA A: Double-strand breaks: signaling pathways and repair mechanisms. Cell Mol Life Sci 61: 2137-2147, 2004.

LANDOLT AM, HALLER D, LOMAX N, SCHEIB S, SCHUBIGER O, SIEGFRIED J, WELLIS G: Stereotactic radiosurgery for recurrent surgically treated acromegaly: comparison with fractionated radiotherapy. J Neurosurg 88: 1002-1008, 1998.

LANDOLT AM, HALLER D, LOMAX N, SCHEIB S, SCHUBIGER O, SIEGFRIED J, WELLIS G: Octreotide may act as a radioprotective agent in acromegaly. J Clin Endocrinol Metab 85: 1287-1289, 2000.

MAREKOVÁ M, ČÁP J, VOKURKOVÁ D, VÁVROVÁ J, CERMAN J: Effect of therapeutic doses of ionising radiation on the somatomammotroph pituitary cell line, GH3. Endocr J 50: 621-628, 2003.

MINNITI G, JAFFRAIN-REA ML, ESPOSITO V, SANTORO A, TAMBURRANO G, CANTORE G: Evolving criteria for post-operative biochemical remission of acromegaly: can we achieve a definitive cure? Endocr Relat Cancer 10: 611-619, 2003.

PATEL YC: Somatostatin and its receptor family. Front Neuroendocrinol 20: 157-198, 1999.

SELLERS LA, ALDERTON F, CARRUTHERS AM, SCHINDLER M, HUMPHREY PP: Receptor isoforms mediate opposing proliferative effects through G $\beta \gamma$-activated p38 or Akt pathways. Mol Cell Biol 20: 5974-5985, 2000.

TAKAHASHI A, OHNISHI T: Does gammaH2AX foci formation depend on the presence of DNA double strand breaks? Cancer Lett 229: 171-179, 2005.

THEODOROPOULOU M, ZHANG J, LAUPHEIMER S, PAEZ-PEREDA M, ERNEUX C, FLORIO T, PAGOTTO U, STALLA GK: Octreotide, a somatostatin analogue, mediates its antiproliferative action in pituitary tumor cells by altering phosphatidylinositol 3-kinase signaling and inducing Zac1 expression. Cancer Res 66: 1576$1582,2006$.

VÁVROVÁ J, MAREKOVÁ-REZAČOVÁ M, VOKURKOVÁ D, SZKANDEROVÁ S, PSUTKA J: Caffeine induces a second wave of apoptosis after low dose-rate gamma radiation of HL-60 cells. Radiat Environ Biophys 42: 193-199, 2003.

VOKURKOVÁ D, ŠINKORA J, VÁVROVÁ J, ŘEZÁČOVÁ M, KNÍŽEK J, ÖSTEREICHER J: CD8 ${ }^{+}$natural killer cells have a potential of a sensitive and reliable biodosimetric marker in vitro. Physiol Res 55: 689-698, 2006.

WENDT J, RADETZKI S, VON HAEFEN C, HEMMATI PG, GUNER, D, SCHULZE-OSTHOFF K, DORKEN B, DANIEL PT: Induction of $\mathrm{p} 21 \mathrm{CIP} / \mathrm{WAF}-1$ and $\mathrm{G}_{2}$ arrest by ionizing irradiation impedes cacpase-3-mediated apoptosis in human carcinoma cells. Oncogene 25: 972-980, 2006. 